POLLACK PERIODICA

An International Journal for Engineering and Information Sciences

DOI: $10.1556 / 606.2016 .11 .1 .13$

Vol. 11, No. 1, pp. 145-155 (2016)

www.akademiai.com

\title{
COMMUNITY PARTICIPATION IN SUSTAINABLE URBAN GROWTH, CASE STUDY OF ALMERE, THE NETHERLANDS
}

\author{
Szabolcs PORTSCHY \\ Department of Freehand Drawing, Budapest University of Technology and Economics \\ Müegyetem rkp.3, H-1111 Budapest, Hungary, e-mail: szabolcsportschy@rajzi.bme.hu
}

Received 1 January 2015; accepted 18 June 2015

\begin{abstract}
The city of Almere, which is one of the four main cities in the Amsterdam Metropolitan Area, has been among the fastest growing cities in Europe ever since it establishment in 1976. The economic and demographic expansion puts significant pressure on valuable green areas around Amsterdam, and Almere has both space and potential for growth. Already at the time of its creation, the plans of a multiple-core structure city attracted mixed reviews, leading urban designers calling it 'an anti-city'. However, with time it has developed into a mature, healthy and sustainable urban environment. With the new expansion that would add 60.000 new dwellings and 100.000 new jobs by 2030, the city faces new challenges, which require visionary strategic planning once again.

The intended growth of Almere is planned to take place in an ecologically, socially and economically sustainable fashion. To achieve this and to inspire contribution to future developments, the city has defined seven principles in concurrence with international sustainability experts.

Community participation is one of the strongest principals in this innovative place-making experiment. Creators of the new strategic vision imagine large-scale citizen involvement, bottomup community and private initiative through empowerment and ownership, from the design phase to the implementation. They aim far beyond the design character of the buildings, including among others the design of the urban fabric and the supporting infrastructure as well. This paper intends to describe and examine the potential growth and the urban development of Almere from a complex perspective, with a special focus on community design.
\end{abstract}

Keywords: Almere, Community participation, Community design, Bottom-up urban development, Sustainable urban growth, Poly-nuclear city 


\section{The poly-nuclear city}

The birth of Almere coincides with the latest phase of the grand scale land reclamation projects of the Netherlands. In the 20th century alone, close to 170.000 hectares of new land was created. From the originally planned five polders four have been completed by the 1970s. Designed originally for agricultural purposes, with the change of time, economic and demographic pressure, the land soon became used for alternative purposes. While the first polders were created relatively far from the main urban agglomeration, the later phases of the development created new land nearer to that area, providing a good opportunity for urban expansion [1]. In order to preserve the so-called 'green heart' around, which the 'Randstad', the major urban areas of Amsterdam, Utrecht, Rotterdam and den Hague are located, population pressure and new economy were directed outwards, towards existing smaller towns and newly created settlements.

Almere emerged as a major destination for the urban growth [1]. The original design of the city featured a system of semi-separate urban nuclei (Fig. 1).

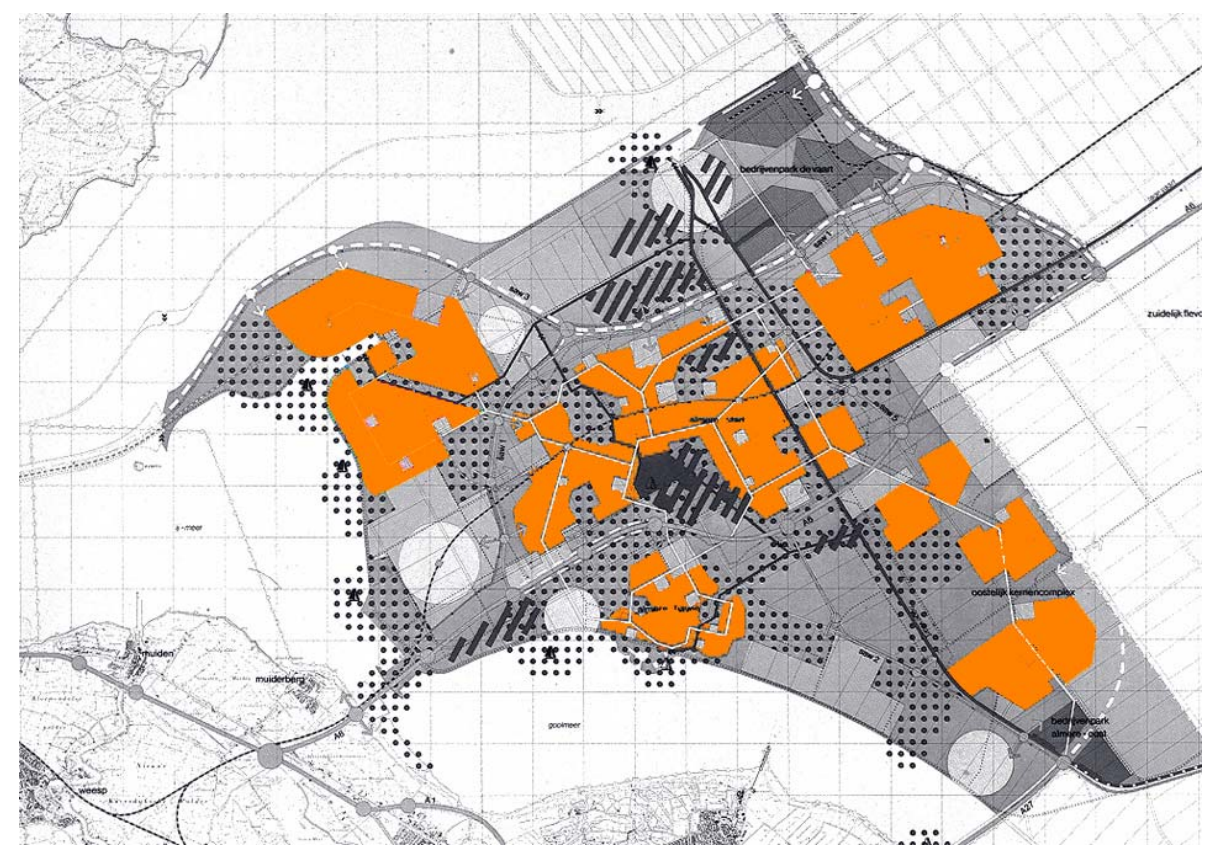

Fig. 1. The original poly-nuclear concept, Teun Koolhaas Assoc, Almere, 1977, (with the written permission of the copyright owner)

In this unique layout each nucleus has a distinct character with its neighborhoods and necessary facilities [2]. While sharing the same city center and the main infrastructure (a thoughtfully planned road system (with exclusive bus lanes) and an extensive bicycle path network [3], [4]), the urban units are separated from each other 
by generous green land (parks, woodlands, agricultural lands) that comprise close to $75 \%$ of the city area. The poly-nuclear design has allowed for great flexibility necessary to adjust to changing circumstances: areas with differing density and size, green open spaces within more dense urban areas, and for the city to be developed in stages that ensures successful operation even if complete build-out has not been achieved [1]. In this concept, each nucleus could learn from the positive or negative experiences of previously built districts.

Almere-Haven was the first nucleus to be developed in 1976. The district is located at the southern coast of South Flevoland, providing an attractive environment to new homeowners. Almere-Stad followed four years later. Designed as a central nucleus it was developed with a more urban character, yet without high-rises and a traditional city center. First constructions in Almere-Buiten started in 1984, and in Almere-Hout in 1991. The youngest district Almere-Poort has been developed since 2009, in the frame of the new city development strategy, with the active involvement of its future residents in the urban character of the district. The same strategy includes conceptual plans for future districts: Almere-Oosterwold, Almere-Pampus and Almere IJland.

While Almere has been regarded as one of the 'dormitory towns' from where residents are content to travel for both work and active recreation [5], a dedicated area was set aside for a potential city center to be developed at later stages. By the 1990 s the commercial and recreational facilities and economic opportunities available in Stad were far behind the population's needs. At the same time, there was a desire to steer the city away from its heavy dependence on commuting and towards a more sustainable model. In 1994, a new planning process begun - resulting in a master plan competition for the vacant site (that was purposely left undeveloped at the central area of the city) with a design scope that encompassed both business, cultural, recreational, and civic facilities, the contemporary components of a new city center [5]. The winning concept was created by Rem Koolhaas's OMA, and it included a new business center, Zakencentrum, and a larger mixed-use district, Stadshart. The plan interestingly went against everything that had characterized the rest of the city: it broke out of the grid with a set of diagonal directions, and featured a high density and high-rise urban structure. Construction began in 1999 and the majority of the buildings were completed by 2007 [6].

\section{The sustainable city}

At the time of creating Almere urban, physical spatial, cultural and economic planners made an attempt to mix a wide selection of approaches and concepts from the garden city school, through the ecological city movement to recent trends with focus on sustainability and smart growth [7]. The original design of Almere has been considered the best modern effort in implementing Ebenezer Howard's Garden City vision [8].

Almere's comprehensive plan emphasized a greener character for its nuclei. Low density housing (38 houses per hectare [2]) within walking distance from workplaces, schools, public transportation and recreational facilities was the key element in the plan. According to a 1991 study the modal split of commuting were: $35 \%$ car, $17 \%$ public transit, $28 \%$ bicycle and $20 \%$ walking [9]. Due to extensive bicycle network 
infrastructure development (including the construction of a bicycle superhighway system) since then and scheduled until 2020, these proportions have shifted toward bicycle riding even further [10].

In addition, the city features considerable amount of open landscape, extensive vegetation that infiltrate residential areas, planned green buffered zones with recreational and transportation functions, and the overall the incorporation of green ecological elements into and outside the neighborhoods [7]. Despite the amount of green area, the quality of the green zones, their proximity to the urbanized areas and the integrity with the city leave space - but also offer opportunities - for development [11]. A new comprehensive development strategy - discussed in detail in the fourth chapter of this study - aims to address these arrears by creating special transitional, recreational, spiritual and educational points where the city can meet the nature [11].

In meeting development challenges, Almere considers sustainability a key factor. The current leaders of the city imagine the intended growth of Almere to take place in an ecologically, socially and economically sustainable fashion. Their joint desire is nothing less than to turn Almere into an 'icon of sustainability' [2]. Reflecting on this endeavor, the municipality worked out a set of principles to inspire future sustainable development. These principles are as follows: cultivate diversity, connect place and context, combine city and nature, anticipate change, continue innovation, design healthy systems and empower people to make the city [2]. As Timothy Beatley states in his book Green Urbanism: Learning from European Cities: in order to create a sustainable city there is a great need for innovative local, regional and national planning concepts, strategies and policies that combine and integrate environmental and ecological components with the spatial, morphological, cultural, social and economical ones. He suggests that Almere has managed to synthesize multiple greener, sustainable city approaches and captures, in multiple ways, the efforts to achieving a greener, more sustainable, more positive urban planning [12].

\section{The self-built city}

The original plans of Almere included the idea of a limit to population growth to about 250.000. Because of the rapid growth during the past few decades, population was expected to reach this cap by around 2010 [4]. The growth slightly slowed down, and by the beginning of 2014 the population was estimated a little over 196.000 [13]. Still, in an effort to provide relief and to offer new qualities to the dense, urbanized northwestern region of the Netherlands, the central and provincial governments have asked Almere to expand [2]. The city started working on a new master plan to take the city to 350.000 residents by 2030 . The new accelerated increase strategy, called 'Schaalsprong Almere', includes complex and comprehensive development schemes in three new districts [14].

Almere-Poort was the first new nucleus to be created in the frame of the new expansion program. The latest and probably the most interesting phase of the ongoing development is a 100-hectare self-build zone in the district, called Homeruskwartier, which has been propelled from drawing board to part-built reality in just five years [15]. Self-built housing and citizen participation in urban development projects are key 
elements in the policy of Adri Duivesteijn, a Dutch Member of the Parliament for the Labor Party. Duivesteijn considers Almere a success story but pointed out a few downsides in the city's development: citizens of Almere were not involved in the development of their city, since most building projects in Almere were carried out in a top down fashion, according to blueprints. Also, emphasis was often on quantity rather than on quality, where houses were built in the same or very similar character [16]. As the Deputy Mayor of the city back in 2006, he gave the opportunity to realize his ideas. Jacqueline Tellinga from the Netherlands Architecture Institute in Rotterdam was invited as project manager and OMA was again hired to work on a master plan [15].

The site of the new development was divided into 720 individual plots of varying sizes, plus a higher-density, mixed-use central area, where future tenants could team up and build multi-family apartment blocks, office or retail space (Fig. 2). Potential buyers were provided with every necessary detail of infrastructure specifications and conditions that could have any effect on their future buildings, beforehand [15].

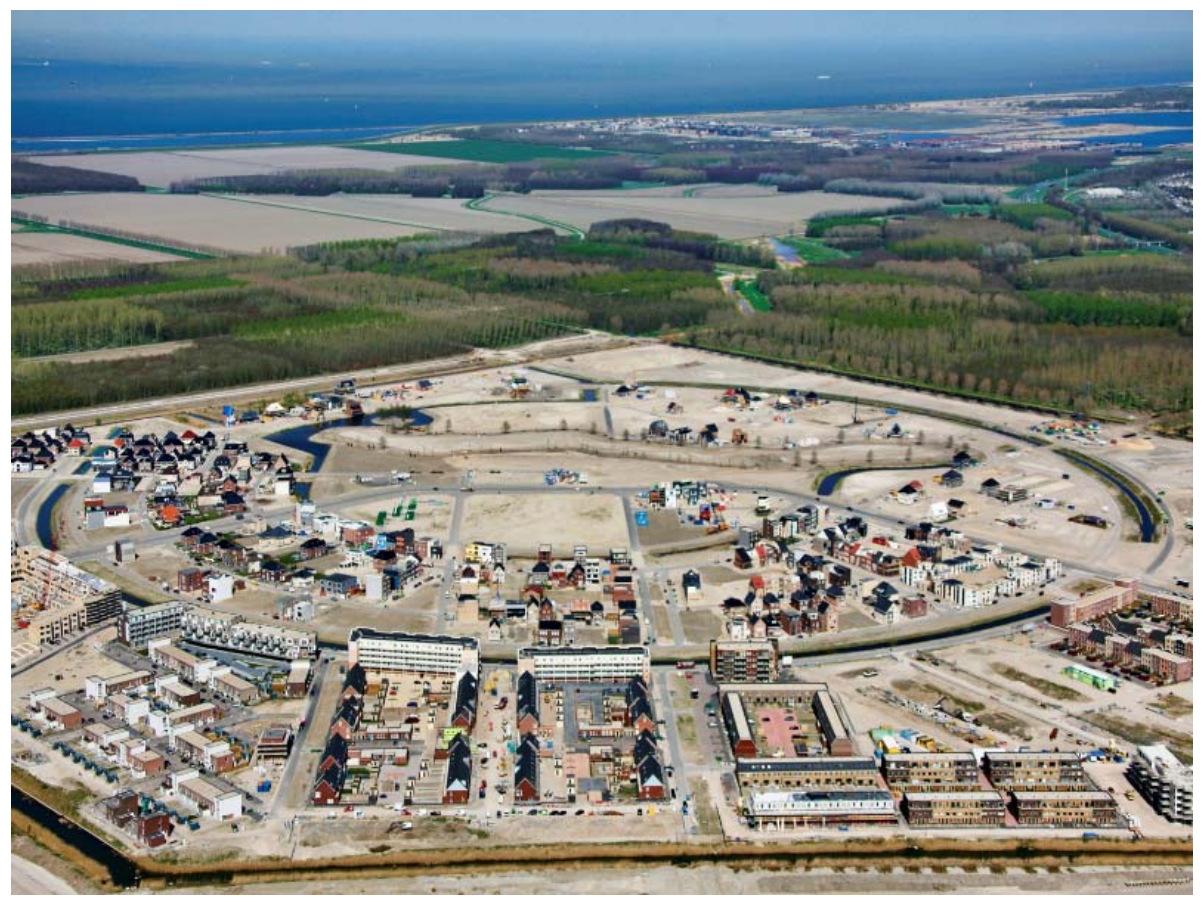

Fig. 2. Aerial photo of Homeruskwartier, Topshot.nl, Adri Duivesteijn; 2013, (with the written permission of the author)

Residential plots were classified into 26 zones, all branded with a prefix 'I Build...' and then specific suffixes, like: 'sustainable', 'live-work', 'terraced', 'timber-clad', 'extra', 'free', 'town center', 'canal houses', 'garden homes', 'affordable', etc. referring to the building-type required on that area. This gives the relative freedom for future homeowners to build what they like with certain limitations on the size and character. 
By 2014 , over $90 \%$ of the plots have been sold [17]. Since the city does not have to make a profit on the land, plots are sold at an affordable price, while it is up to the creativity of the buyer and their architect how low construction costs would be. Some managed to keep it under $€ 100 /$ sq. m [15] thus making self-build a very attractive option.

Although the city council even held 'meet the architect' events for new buyers, the aesthetic outcome of the project has been mixed. Some buyers had been exposed to a limited architectural stylebook before creating their own home, others chose cheap reproductions of villas found in catalogues, or bought kit houses. Surprisingly, some of the most characterless houses were built in zones with the fewest rules, while the relative freedom resulted some really innovative designs as well [18]. Tellinga argues that the process is more important than the physical outcome and that "self-building leads to more socially cohesive cities whose inhabitants have much stronger attachment to their surroundings [15].

This experiment represents a type of a broader approach called community participatory design. The methodology, which originally developed in parallel with the civil right movements in the United States, is a form of planning that integrates the users of buildings or the built environment into their concept, design, building and maintenance. Through active participation, it aims to promote the sense of ownership, addresses environmental inequities while trying to maximize user satisfaction [19]. Community design methodology underwent significant development, change and varying popularity during the past decades. With the recent emergence of sustainability awareness and environmental concerns, the idea of citizen participation in the shaping of the built environment, and hence the practice of community design has been pushed back into mainstream.

At about 68\% [20], home ownership rate in the Netherlands and especially the number of self-build homes has traditionally been relatively low compared to other European countries. The success of the new model implemented in Poort has attracted international attention, especially from the UK, where housing shortage is causing noticeable crisis, and self-build is seen as a plausible answer [21].

\section{The future city}

After a series of community consultation, the Municipality of Almere set a number of guidelines in the Draft Structural Vision Almere 2.0, defining a sustainable urban development strategy of the city until 2030.

With almost doubling the area and population of the city, the ecological, social and economic diversity is going to increase and the relative imbalance - in dwelling types, urban amenities, natural resources population composition and employment - inherent in a young town like Almere needs to be enriched. While other urban areas have centuries to do this, Almere is planning to achieve it in a mere period of 20 years. The strategy does not intend to intervene in the existing urban area in the context of the leap of scale. Instead, the current identities of the districts will be reinforced. At the same time the construction of 60.000 new homes will put pressure on the competitive position on certain districts [14]. The development will follow the poly-nuclear character of 
Almere with the creation of new districts (Almere Pampus, Almere IJland and Almere Oosterwold).

The city is exceptionally rich in green and blue areas, which is a rare quality in the densely populated Netherlands. Green areas like Boswachterij and Pampushout currently on the periphery of the city - will be integrated, serving as the recreational urban forestry of Almere. The expansion program also has a special focus on the water land, with improvement of the ecology of Markermeer and IJmeer [14].

The main features of the strategy however reflect on the various effects of the almost 150.000 new inhabitants. These changes are expected to transform the city's life significantly. Almere city officials consider citizens as the main driving force behind the city, as people utilize the entire range of facilities - culture, sport, entertainment, recreation and employment - that the various cities of a metropolis offers [14].

The additional population, and the increasing diversity will require the development of the current infrastructure and public transportation system, which includes new train connections with Amsterdam and Utrecht, the broadening of the motorway that crosses the city, but at the same time converting its central section into an underpass. The intervention is expected to create new easily accessible development space for additional metropolitan amenities right in the center [14].

From community participation aspects, the most unique part of the Draft Structural Vision is the new district: Oosterwold. Oosterwold, currently an extensive farmland, will be created as a low-density countryside living and working milieus. Acting as a counterpart of the more planned central districts, it will concentrate entirely on the historical patterns of organic urban development. The Municipality of Almere hired $M V R D V$, who came up with a proposal, an urban development template for a DIY project that will transfer power into the hands of neighborhoods and communities. The new development strategy is designed to be bottom-up, inclusive and intuitive to the needs of individuals and their communities. As a main feature it allows the design to develop organically and over a longer period of time reflecting the change of needs as neighborhoods grow, age and transform [22].

The Municipality imagines the land to begin integrating elements of the built environment in innovative ways that preserve the landscape. MVRDV has worked out a scheme with a combination of programs and building typologies, but the general layout of the district will be allowed to evolve organically. The designations that have been established to guide the development are designed to promote differentiation while preserving character of the landscape [22].

Half of the area has been designated to urban farming that will provide food production for the city. Buyers can choose from different types of lots (agricultural, landscape, urban or standard housing lot) at any size or shape (Fig. 3). By clustering their buildings, owners contribute to the development to an open and continuous green landscape. Owner also contributes to a street network with the construction of their part of a public road, a path around their lot, and access road to their land. Open space on the lot can be filled with urban farming and the owner's share of public green. In the proposal, owners are responsible for the retention and drainage of rainwater, the production of renewable energy, providing clean drinking water and the processing of waste. The first residents realize their lots scattered in the open landscape, then step-by- 
step the first communities will be created, and eventually a versatile neighborhood comes to life, a landscape designed by its residents [23].

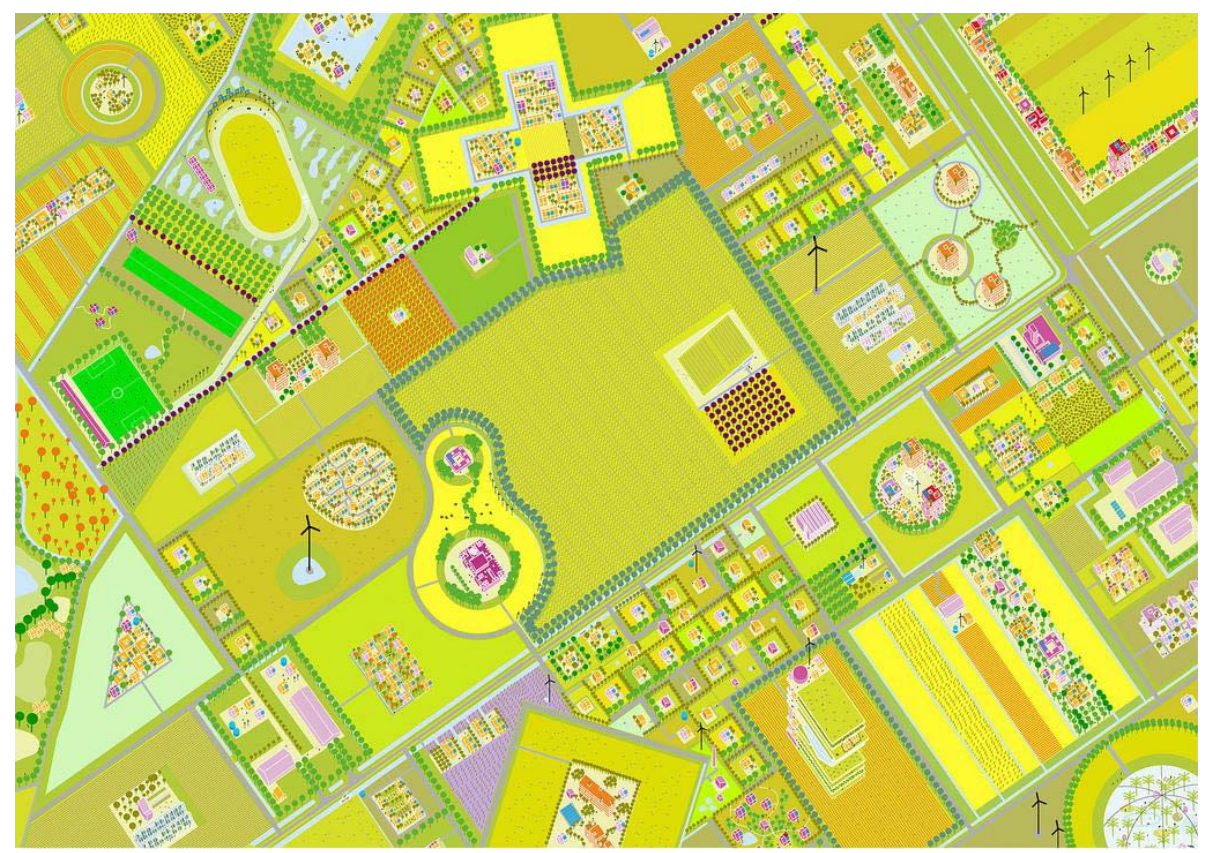

Fig. 3. Conceptual organic urban layout; Project: Almere Oosterwold, Almere, Netherlands (2011/-), Urban Planner: MVRDV, Rotterdam, Netherlands (with the written permission of the copyright owner)

\section{Present and future challenges}

While both the municipality's elaborated vision on the future and the groundbreaking urban development initiatives reflect strong optimism, a few questions have remained open, most of which may only get answered with time and through experience. Regardless, those answers will determine the future success of Almere substantially.

How can urban growth of this nature take shape responsibly? Almere is pursuing a growth strategy, which is unprecedented even in the city's dynamic population history, and which will certainly be of a very different character than before.

What are the foreseeable social challenges? The majority of Almere's first 'pioneers' were middle class Dutch families, primarily from Amsterdam, looking for a quieter and greener living environment and benefitting from the proximity of the metropolitan area as well [14]. Since then, Almere has become the best example of what the Netherlands population as a whole may look like in the future. The city enjoys an exceptionally rich ethnic and social diversity: immigrants from over 200 countries make up close to $40 \%$ of the entire population [24]. While the municipality of Almere has 
been promoting a city proud of its heterogeneity, even here, citizens are divided over the Dutch immigration policy. At the local elections in 2010 [25], and again in 2014 [26], PVV the populist anti-immigration and anti-Islam party won the most seats in the city council. Although, the party has been unsuccessful in finding coalition partners, the more than $20 \%$ popularity of PVV is a clear sign of the citizens' mixed standpoint on ethnic diversity.

How to preserve and reinforce the original qualities, while simultaneously meeting the demand for growth? Despite its relative short history, Almere managed to establish a number of qualities that make the city what it is today. The suburban character that has been one of the most attractive features of Almere will face significant challenge with the expansion.

How to create the sense of ownership and preserve it for the generations to follow? The new urban development program of Almere relies heavily on community involvement. Citizen participation and shared responsibility are great tools in creating a healthy sense of ownership. However, ways of passing that sense onto the next generations need to be evolved.

What level of community involvement guarantees that the needs of the people shape the potency of the city? Community involvement in the shaping of the built environment has had a very long tradition. The shared cultural, social and historical roots and the mutual knowledge has resulted the extreme richness of vernacular architecture all over the world.

How to form communities from new pioneers with different backgrounds? Alienation is one of the most striking side effects of the rapidly increasing social mobility. Forming communities require bottom-up initiative. In these new diverse communities, the cohesive force of multi-generation-long living together - which formed the bond in traditional communities - needs to be substituted with alternative stimuli.

\section{Conclusion}

Since the time of its creation, Almere has been open to innovative and experimental solutions in urban development and it has successfully overcome the challenges of the past four decades. Its residents and their elected leaders have demonstrated their proactive engagement in the thoughtful development of their city several times.

Yet again, Almere is facing a substantial challenge, and its municipality does not seem to fall short of revolutionary ideas. Based on comprehensive public consultations, the city has laid down a set of progressive principles and has been resolutely acting upon them.

While Almere's mid-term strategy shows an unquestionable commitment to sustainability, progress, community engagement and a healthy urban environment, there are a number of social and political concerns and uncertainties that may affect the results. Many of these issues are not specific to Almere alone, but present continentwide, or even global problems. For this reason, if the new development strategies prove to successfully address these issues, Almere may set an adaptable example for other cities as well. 


\section{References}

[1] Constandse A. Almere: A new town in development: problems and perspectives, Journal of Housing and the Built Environment, Vol. 4, No. 3, 1989, pp. 235-255.

[2] Gemeente Almere, Official website of the city of Almere, http://english.almere.nl/the-cityof-almere/ (last visited 3 February 2014).

[3] Killing A. OMA: Almere's new city centre, Blueprint, Architecture and Design, No. 263, 1989, pp. 21.

[4] Planum Magazine, Cultural Identities: Almere (The Netherlands), Development of new city centre (1999 - 2007), http://www.planum.net/cultural-identities-almere-the-netherlands (last visited 3 February 2014).

[5] Woodman E. Growing pains, Review of the masterplan for Almere, Building Design, No. 1614, 2004, pp. 12-15.

[6] Webb B. Almere, New town center, http://courses.umass.edu/latour/2010/almere/ (last visited 3 February 2014).

[7] Newman M. Almere new city, Sustainable city, Ideal city? An urban morphological analysis of the newest Dutch city, No. 21, (Fall/Winter 2009-2010), 2009, pp. 13-20.

[8] Newman P.; Kenworthy J. Sustainability and cities, Overcoming automobile dependence, Island Press, USA, 1999, pp. 169.

[9] Roberts J. Changed travel, better world? A study of travel patterns in Milton Keynes and Almere, TEST, London, 1999, pp. 61.

[10] Almere Bike City, de duurzame stad is een fietsstad, Official issue of the Dienst stedelijke Ontwikkeling Almere and Afdeling Stedenbouw en Verkeer, 2013, pp. 15-52.

[11] Duivesteijn A. Green city Almere, Speaker presentation from the conference, Growing Green Cities, Floriade Almere 2022, 20 September 2012.

[12] Beatley T. Green urbanism, Learning from European cities, Island Press, 2000, pp. 200, pp. 408.

[13] CBS (Statistics Netherlands), Almere Population, 2014, http://statline.cbs.nl/StatWeb/ publication/ (last visited 3 February 2014).

[14] Draft structural vision Almere 2.0, Summary, Digital publication by the municipality of Almere, 2009, http://english.almere.nl/fileadmin/files/almere/subsites/english/Draft_ strategic_vision_Almere_2.0.pdf (last visited 3 February 2014).

[15] Hopkirk E. The Netherlands' Almere leads the way on self-build communities, Building Design Online, 6 June 2011, http://www.bdonline.co.uk/the-netherlands-almere-leads-theway-on-self-build-communities/5019196.article (last visited 3 February 2014).

[16] Duivesteijn A. Self-build housing, A huge untapped potential, Speaker presentation from the Self-build Summit 16 October 2012, http://www.local.gov.uk/c/document_library/ get_file?uuid=6c99ebf3-a377-4b87-bcdf-67476e36aa13\&groupId=10180 (last visited 3 February 2014).

[17] De Kavelwinkel, The official municipality real estate agency of Almere, http://www.ikbouwmijnhuisinalmere.nl/ (last visited 3 February 2014).

[18] Jones A. Self-build \& the Amsterdam School, Jones the planner, 30 September 2012, http://www.jonestheplanner.co.uk/2012/09/self-build-amsterdam-school.html (last visited 3 February 2014).

[19] Curry T. Community design methodology, http:/www.amdgdesign.org/AMDGdesign/ Method.html (last visited 3 February 2014).

[20] Eurostat, Distribution of population by tenure status, type of household and income group, 2012, http://appsso.eurostat.ec.europa.eu/nui/ (last visited 3 February 2014).

[21] Collinson P. Self-build, it's time to go Dutch, The Guardian Online, 2 November 2011, http://www.theguardian.com/money/2011/nov/25/self-build-go-dutch (last visited 3 February 2014). 
[22] Vinnitskaya I. D. I. Y Urbanism, Almere Oosterwold/MVRDV, 22 April 2012, http://www.archdaily.com/227503/d-i-y-urbanism-almere-oosterworld-mvrdv/ (last visited 3 February 2014).

[23] MVRDV, Almere Oosterwold (Official Project Website), http://www.mvrdv.nl/projects/ oosterwold/ (last visited 3 February 2014).

[24] RIVM Zorgatlas, Niet-westerse allochtonen per gemeente 2010-2040, http://www. zorgatlas.nl/beinvloedende-factoren/demografie/etniciteit/niet-westerse-allochtonen-pergemeente-2010-2040/ (last visited 3 February 2014).

[25] NOS, PVV 1ste in Almere, 2de in Den Haag, 3 April 2010, http://nos.nl/artikel/141343-pvv1ste-in-almere-2de-in-den-haag.html, (last visited 3 February 2014).

[26] HetPAROOL, Grootste partij PVV in Almere op voorhand afgewezen door mogelijke partners, http://www.parool.nl/parool/nl/14048/GEMEENTERAADSVERKIEZINGEN2014/article/detail/3619344/2014/03/20/Grootste-partij-PVV-in-Almere-op-voorhandafgewezen-door-mogelijke-partners.dhtml (last visited 3 February 2014). 